\title{
ПСИХОЛОГІЧНЕ БЛАГОПОЛУЧЧЯ: ТЕОРЕТИЧНІ ПІДХОДИ ДО ВИЗНАЧЕННЯ ПОНЯТТЯ
}

\author{
Можаровська Тетяна \\ Поліський національний університет, \\ м. Житомир, Україна, \\ mozharovska.t@gmail.com \\ ORCID: https://orcid.org/0000-0001-9628-2994
}

Мета. В останні десятиліття стрімко збільшилось досліджень про щастя, що призвело до появи нових емпіричних знань про механізми, шляхи, особливості та процеси, які сприяють особистісному щастю та благополуччю. В умовах сьогоднішньої світової пандемії, спричиненої коронавірусом SARS COV-2, більшість людей опинилися в незвичних для них умовах, що вплинуло на зміну стилю та способу життя кожного. Людству довелося шукати нові шляхи забезпечення та реалізації власного благополуччя та благополуччя інших. Мета статті полягає в теоретичному аналізі дослідження проблеми психологічного благополуччя особистості.

Методи. Для уточнення сутності базових понять досліджуваного феномену застосовано теоретичні методи, зокрема, аналіз, синтез, узагальнення, систематизація й теоретичне моделювання.

Результати. У результаті теоретичних розвідок з цієї проблеми здійснено аналіз підходів до визначення благополуччя та його видів. Виявлено тенденцію об'єднання різних теорій та підходів аналізу психологічного й суб' єктивного благополуччя до єдиного комплексного вивчення благополуччя. Описано компоненти психологічного благополуччя.

Висновки. Висновки наукових розвідок досліджуваного феномену включають опис та обгрунтування вимірів психологічного благополуччя, а саме: особистісний, соціальний, матеріальний, фізичний та духовний. Особистісний вимір психологічного благополуччя враховує суб'єктивний показник внутрішнього відчуття щастя та комфорту. Соціальний контекст психологічного благополуччя обумовлюється мірою задоволеності особистістю якістю своїх міжособистісних відносин, соціальних ролей та соціального статусу. Матеріальний вимір психологічного благополуччя визначається суб'єктивною оцінкою реального достатку особистості та об'єктивного співставлення останнього 3 бажаним достатком; визначається наявністю можливості задовольнити вітальні потреби особистості та сприяють ії духовному розвитку. Фізичний вимір психологічного благополуччя визначається рівнем здоров'я людини та передбачає наявність потенційних

ISSN 2308-3743 (Online), ISSN 2227-1376 (Print)

(C) Можаровська Т., 2021. Ця стаття відкритого доступу на умовах CC BY-NC 4.0 
(резервних) можливостей організму, адекватність пристосування до змін навколишнього середовища, толерантність до непередбачуваних і стресових подій. Духовний вимір психологічного благополуччя визначається належністю особистості до культури та спільноти, з якою себе ідентифікує особистість; передбачає критичне ставлення до себе та своєї діяльності.

Ключові слова: психологічне благополуччя, суб’єктивне благополуччя, щастя, психологічне здоров'я.

\section{Mozharovska Tetiana. Psychological well-being: theoretical approaches to the concept definition.}

Purpose. In recent decades, the number of studies of happiness has increased rapidly, which led to the emergence of new empirical knowledge about the mechanisms, ways, peculiarities, and processes that contribute to a personality's happiness and well-being. In today's world pandemic terms caused by coronavirus SARS-COV-2, most people found themselves in unusual conditions, which influenced the change of style and lifeway of everyone. People had to look for new ways to ensure and implement their wellfare and the well-being of others. The purpose of the article lies in the theoretical analysis of the study of the problem of psychological well-being of a personality.

Methods. The theoretical methods are used, in particular, analysis, synthesis, generalization, systematization, and theoretical modelling to clarify the essence of the basic concepts of the researched phenomenon.

Results. The analysis of approaches to the determination of well-being and its types is carried out as the result of theoretical surveys on this issue. The tendency to combine different theories and approaches to the analysis of psychological and subjective well-being into the single complex study of wellbeing is revealed. The components of psychological wellbeing are described.

Conclusions. The conclusions of scientific investigations of the researched phenomenon include the description and grounding of the dimensions of psychological well-being, namely: personality, social, material, physical and spiritual. The personality dimension of psychological well-being considers the subjective indicator of the inner feeling of happiness and comfort. The social context of psychological well-being is conditioned by the degree of personality's satisfaction with the quality of own interpersonal relationships, social roles and social status. The material dimension of psychological well-being is predetermined by the subjective assessment of the real wealth of a personality and the objective comparison of the latter with the desired one. It is defined by the ability to meet the vital needs of a personality and contribute to spiritual development. The physical dimension of psychological well-being is determined by the level of human health and implies the presence of potential (reserve) abilities of organism, adaptation adequacy to the environmental changes, tolerance to unpredictable and stressful events. The spiritual dimension of psychological well-being is determined by a personality's affiliation to the culture and community with which this personality is identified; involves a critical attitude towards oneself and own activities. 
Keywords: psychological well-being, subjective well-being, happiness, psychological health.

\section{Можаровская Татьяна. Психологическое благополучие: теоретические подходы к определению понятия.}

Цель. В последние десятилетия количество исследований счастья быстро возросло, что привело к появлению новых эмпирических знаний о механизмах, путях, особенностях и процессах, способствующих личному счастью и благополучию. В контексте сегодняшней глобальной пандемии, вызванной коронавирусом SARS - COV-2, большинство людей оказалось в необычных условиях, что повлияло на изменение стиля и образа жизни каждого. Человечество должно теперь искать новые пути обеспечения и реализации собственного благополучия и благополучия других людей. Целью статьи является теоретический анализ проблемы психологического благополучия личности.

Методы. С целью конкретизации основных понятий исследуемого феномена использовано теоретические методы, в частности, анализ, синтез, обобщение, систематизация и теоретическое моделирование.

Результаты. В результате теоретических поисков исследуемого феномена проведен анализ подходов к определению благополучия и его типов. Выявлена тенденция к объединению различных теорий и подходов анализа психологического и субъективного благополучия к единому всестороннему изучению благополучия. Описаны составляющие психологического благополучия.

Выводы. Выводы научных поисков исследуемого феномена включают описание и обоснование аспектов психологического благополучия, а именно: личностного, социального, материального, физического и духовного. Личностное измерение психологического благополучия учитывает субъективный показатель внутреннего чувства счастья и комфорта. Социальный контекст психологического благополучия вызван в меру удовлетворенности личности качеством межличностных отношений, социальной роли и социального статуса. Материальное измерение психологического благополучия определяется субъективной оценкой реального процветания индивидуума и объективной корреляцией последнего с желаемым изобилием; определяется способностью удовлетворять живые потребности человека и способствовать его духовному развитию. Физическое измерение психологического благополучия определяется уровнем здоровья человека и подразумевает наличие потенциальных (резервных) возможностей организма, адекватность адаптации к изменениям в окружающей среде, терпимость к непредсказуемым и стрессовым событиям. Духовное измерение психологического благополучия определяется принадлежностью индивидуума к культуре и общине, с которыми человек идентифицирует себя; критическое отношение к себе и своей деятельности. 
Ключевые слова: психологическое благополучие, субъективное благополучие, счастье, психологическое здоровье.

Вступ. Науковий тезаурус сучасної психології часто ототожнює поняття психологічне благополуччя, суб'єктивне благополуччя та щастя. Хоча фундаторами вивчення цього феномену розглядаються певні відмінності. Зокрема, Е. Дінер (Diener, 1984) вважає, що суб'єктивне благополуччя виступає як компонент психологічного благополуччя. На сьогодні існує низка досліджень, які засвідчують тісний взаємозв'язок понять психологічне й суб'єктивне благополуччя (Kahneman, Diener, Schwarz, Keyes, Shmotkin, Ryff, 1999), а в зарубіжній психології переважає кількість досліджень, спрямованих на вивчення конкретно суб'єктивного благополуччя (Busseri, Sadava, 2011; Linley, Maltby, Woodc, Osborne, Hurling, 2009; Schimmack, 2008). Саме тому в теоретичному огляді пропонованої статті враховано синонімічний ряд таких понять, як психологічне благополуччя, суб'єктивне благополуччя та щастя.

Методи та процедура дослідження. Мета статті полягає в теоретичному аналізі дослідження проблеми психологічного благополуччя особистості. Для реалізації поставленої мети використано низку теоретичних методів для аналізу наукових джерел досліджуваної проблеми 3 метою узагальнення, порівняння та систематизації наукових даних досліджень феномену психологічного благополуччя.

Обговорення результатів. Психологічне благополуччя постає як багатоаспектний феномен, а підходи до його вивчення беруть початок із філософських традицій - гедонізму (основний ціннісний критерій задоволення або уникнення страждань) (Bradburn, 1965; Waterman, 2008) та евдемонізму (основний принцип життя - щастя) (C. Ryff, E. L. Deci, R. M. Ryan). Згадані традиціï підкреслюють сучасне трактування благополуччя, a також знаходять своє відображення в сучасних та ранніх психологічних теоріях i концепціях благополуччя.

У науковому обігу термін «психологічне благополуччя» визначається як суб'єктивне відчуття щастя та загальної задоволеності життям (Bradburn, 1965).

Феномен психологічного благополуччя в роботах різних авторів описано як баланс між позитивними та негативними емоціями, що 
накопичуються впродовж життя (Bradburn, 1969); суб'єктивне благополуччя, що складається 3 трьох основних компонентів задоволення, комплекс приємних (pleasant affect) та неприємних емоцій (unpleasant affect) (Diener, 1984).

Структура психологічного благополуччя за Н. Бредберн (1969) містить два компоненти: позитивний та негативний ефект (Bradburn, 1969). Е. Дінер (1984) доповнює цю структуру складовою «задоволеність життям» (Diener, 1984), наповнюючи ii когнітивним змістом та визначаючи як «суб'єктивне благополуччя» (Diener, 1984). A тому структура суб'єктивного благополуччя за автором містить комплекс позитивних емоцій (високий рівень), комплекс негативних емоцій (низький рівень) та задоволеність життям (висока міра).

Доповнюючи дослідження Н. Бредберна, К. Райфф (1989) виділяє шість основних компонентів психологічного благополуччя: самосвідомість (знання, симпатії та самоприйняття), позитивне ставлення до оточуючих (позитивні відносини, які $є$ життєво значущими для благополуччя та відображають здатність людини співпереживати та проявляти прив'язаність), автономія (почуття незалежності, яке виникає внаслідок прийняття відповідальності за свої дії), управління навколишнім середовищем (здатність визначати та створювати оптимальні умови для зростання, застосовуючи свою здатність контролювати зовнішні та внутрішні фактори), життєва мета (постановка особистісних цілей у межах глобального життєвого напрямку) та особистісне зростання (розвиток особистого потенціалу шляхом вирішення нових задач) (Ryff, 1989, 1995).

На сьогодні спостерігається тенденція об'єднання різних теорій та підходів аналізу психологічного та суб'єктивного благополуччя до єдиного комплексного вивчення благополуччя. Зокрема, Е. Самман (2007) описує сім індикаторів вимірювання благополуччя (як суб’єктивного, так і психологічного): життєвий смисл (мета); потреба в автономії; потреба в компетентності; потреба у зв'язках; предметна задоволеність життям (визначається сферами життєдіяльності); загальна задоволеність життям; щастя. О. Вернік (2019) зазначає, що 2-4 показники відповідають трьом базовим потребам теорії самовизначення (SDT).

Сучасні дослідження психологічного благополуччя здійснюються у двох основних напрямах: вивчення зовнішніх та внутрішніх факторів благополуччя. Найбільша увага в контексті дослідження 
зовнішніх факторів благополуччя зосереджена передусім на таких напрямах:

-дослідження зв'язку між благополуччям та здоров'ям людини (Diener, Chan, 2011; Pressman, Cohen, 2005; Chida, Steptoe, 2008; Chow, Tsao, 2004; Howell, Kern, Lyubomirsky, 2007);

- вивчення зв'язку суб'єктивного благополуччя та матеріального забезпечення (Luhmann, Schimmack, Eid, 2011; Diener, Suh, Lucas, Smith, 1999);

- вивчення зв'язку суб'єктивного благополуччя та адаптації до життєвих подій (Headey, Wearing, 1992; Howell, Kern, Lyubomirsky, 2007; Luhmann, Hawkley, Eid, Cacioppo, 2012; Luhmann, Hofman, Eid, Lucas, 2012; Sarracino, Piekałkiewicz, 2021).

Сучасні дослідження зосереджуються на концептуалізації щастя через призму міжособистісного аспекту, підкреслюючи тим самим необхідність гармонії та зв'язку з іншими людьми (Baranski, Gardiner, Lee, Funder, Zhuravlova ect., 2020).

Значущими залишаються спроби об’єднати внутрішні та зовнішні фактори благополуччя. Так, за результатами досліджень групи авторів, засобами творення щастя є взаємозв'язок доходу, особистих цінностей та життєвої філософії (Sherman, Shavit, Barokas, et al., 2021). Проведене у 2020 році дослідження щастя в умовах карантинних обмежень, спричинених COVID-19, підтверджує відсутність однозначності погляду на феномен серед опитаних українців, зокрема щастя пов'язано 3 явищами духовного, психологічного, соціального та фізичного благополуччя (Литвинчук, Можаровська, 2020). Можна припустити, що дані взаємообумовлюючі аспекти щастя доречно доповнити i матеріальним благополуччям. Адже матеріальні статки сучасних українців суттєво змінилися, а покращення матеріального становища постає як одне $з$ пріоритетних завдань.

У результаті грунтовного дослідження чинників та ресурсів психологічного благополуччя особистості (Каргіна, 2018) виявлено співвіднесеність останніх. Зокрема, до чинників психологічного благополуччя авторка відносить фаталістичне теперішнє, інтелект, довірливість, саморозуміння, свідомість, радикалізм, залученість, відповідальність, зрозумілість, рефлексивність, щастя, самоефективність, суб'єктивну вітальність та задоволеність життям (Каргіна, 2018). Ресурсами психологічного благополуччя є часова 
перспектива, самодостатність, віра в справедливий світ, довіра, екзистенційна сповненість, почуття зв'язності, ідентичність, смисложиттєві орієнтації, осмисленість життям, цінність життя, оптимізм, життєстійкість, самоконтроль, незалежність, сміливість, тощо (Каргіна, 2018).

Дослідження внутрішніх факторів благополуччя охоплюють такі сфери, як сімейне (подружнє) життя, емоції та відчуття, самотність тощо. Звідси вибудовується логічний зв'язок із психологічним здоров'ям особистості, яке визначається ВООЗ як стан благополуччя, в якому людина здатна реалізовувати власні здібності, протистояти життєвим стресам, бути продуктивною та дбати про своє оточення (BOO3). Тому поняття «психологічне здоров'я» часто розглядається синонімічно із поняттям «психологічне благополуччя»

Узагальнюючи основні підходи до розуміння щастя як психологічного феномену, можна виділити основні його акценти, зокрема, задоволеність життям, усвідомленість життя, переважання позитивного емоційного стану, позитивне ставлення до себе i до навколишнього світу. Основними компонентами психологічного благополуччя, на думку зарубіжних та вітчизняних дослідників, 3 такої позиції $є$ наступні: фізичний; духовний; особистісний; соціальний; матеріальний.

У психологічному аспекті важливими залишаються усі виявлені компоненти з урахуванням суб'єктивної значущості, тобто з позиції важливо/не важливо, значущо/не значущо для конкретної особистості. При цьому важливо враховувати середовищнодіяльнісний контекст екопсихологічного підходу до вивчення благополуччя особистості (Вернік, 2019).

Усе зазначене вище є свідченням того, що поняття «психологічне благополуччя» доречно описувати та вивчати через призму особистісного, соціального, матеріального, фізичного й духовного вимірів (рис. 1).

Особистісний вимір психологічного благополуччя враховує суб'єктивний показник внутрішнього відчуття щастя та комфорту.

Соціальний вимір психологічного благополуччя охоплює всі соціальні активності особистості, показник задоволення/незадоволення соціальних потреб та реалізованих ролей, а також сфери життя, які передбачають міжособистісну взаємодію. Соціальний контекст психологічного благополуччя обумовлюється 
мірою задоволеності особистістю якістю своїх міжособистісних відносин, соціальних ролей та соціального статусу.

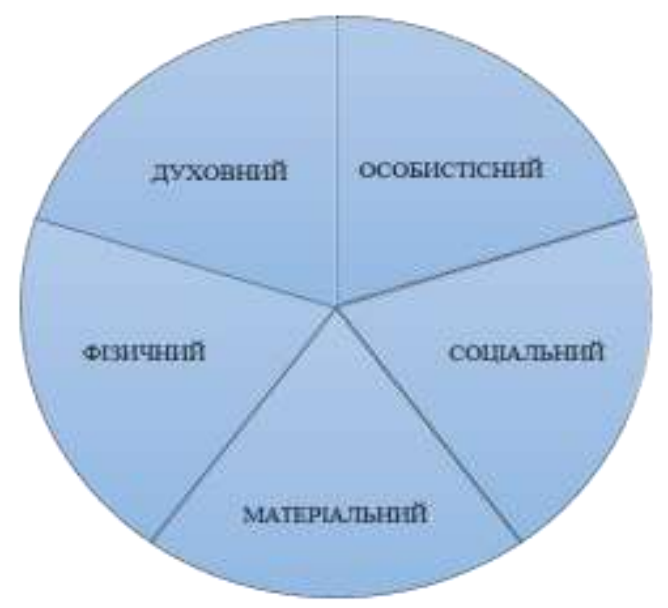

\section{Рис. 1. Виміри психологічного благополуччя}

Матеріальний вимір психологічного благополуччя визначається суб'єктивною оцінкою реального достатку особистості та об'єктивного зіставлення останнього з бажаним достатком. Крім того, матеріальне благополуччя визначається наявністю можливості задовольнити вітальні потреби особистості та сприяє 价 духовному розвитку.

Фізичний вимір психологічного благополуччя визначається рівнем здоров'я людини та передбачає наявність потенційних (резервних) можливостей організму, адекватність пристосування до змін навколишнього середовища, толерантність до непередбачуваних та стресових подій.

Духовний вимір психологічного благополуччя визначається належністю особистості до культури та спільноти, 3 якою себе ідентифікує особистість; передбачає критичне ставлення до себе та своєї діяльності.

Висновки і перспективи. У результаті теоретичного аналізу феномену психологічного благополуччя було встановлено, що не існує єдиного підходу до визначення цього феномену. Натомість виявлено, що такі поняття, як «психологічне благополуччя», «суб'єктивне благополуччя» та «щастя», як правило, вживають у синонімічному значенні. Такий синонімічний ряд прийнято зводити до єдиного комплексного вивчення благополуччя. 
Структура психологічного благополуччя визначається такими компонентами, як самосвідомість, позитивне ставлення до оточуючих, автономія, управління навколишнім середовищем, життєва мета та особистісне зростання.

Психологічне благополуччя забезпечується збалансованим наповненням усіх активних та значущих сфер життя особистості. До таких сфер належать наступні: особистісний, соціальний, духовний, матеріальний, фізичний виміри психологічного благополуччя. Надання кожному виміру особистісної значущості i визначає показник суб'єктивного психологічного благополуччя.

Перспективи подальших досліджень вбачаються в емпіричному вивченні феномену психологічного благополуччя, зокрема у дослідженні особистісного, соціального, духовного, фізичного та матеріального вимірів феномену.

\section{Лiтература} 575 .

1. Diener, E. (1984.) Subjective well-being. Psychological Bulletin, 95, 542-

2. Kahneman, D., Diener, E., Schwarz, N. (1999). Well-being: The Foundations of Hedonic Psychology. NY.: Russell Sage Found, 3-25.

3. Keyes, C. L. M., Shmotkin, D., Ryff, C. D. (2002). Optimizing well-being: The empirical encounter of two traditions. Journal of Personality and Social Psychology, 82, 1007-1022.

4. Busseri, M. A., Sadava, S. W. (2011). A review of the tripartite structure ofsubjective wellbeing: Implications for conceptualization, operationalization, analysis, and synthesis. Personality and Social Psychology Review, 15(3), 290-314.

5. Linley, P. A., Maltb, J., Woodc, A. M., Osborne, G., Hurling, R. (2009). Measuring happiness: The higher order factor structure ofsubjective and psychological wellbeing measures. Personality and Individual Differences, 47, 878884.

6. Schimmack, U. (2008). The structure of subjective well-being. The science of subjective well-being. New York, NY US: Guilford Press, 97-123.

7. Bradburn, N. M. (1965). Reports on Happiness. A Pilot Study of Behavior Related to Mental Health. Aldine Publishing Company. Chicago, USA.

8. Diener, E., Emmons, R., Larsen, R. at al. (1985). The Satisfaction with Life Scale. Journal of Personality Assessment, 49, 71-75.

9. Waterman, A. S., Schwartz, S. J., Conti R. (2008). The implications of two conceptions of happiness (hedonic enjoyment and eudaimonia) for the understanding of intrinsic motivation. Journal of Happiness Studies, 9, 41-79.

10. Bradburn, N. (1969). The Structure of Psychological well-being. Chicago: Aldine Pub. Co. 
11. Ryff, C. D. (1989). Happiness is everything, or is it? Explorations on the meaning of psychological wellbeing. Journal of Personality and Social Psychology, 57, 1069-1081.

12. Ryff, C. D. (1995). The structure of psychological well-being revisited. Journal of Personality and Social Psychology, 69, 719-727.

13. Samman, E. (2007). Psychological and Subjective Wellbeing: A Proposal for Internationally Comparable Indicators. OPHI WORKING PAPER NO. 05.

14. Вернік, О. (2019). Екопсихологічний підхід до дослідження благополуччя особистості: середовищно-життєдіяльнісний контекст. Актуальні проблеми психологї̈, 7(47), 68-79.

15. Diener, E., Chan, M. Y. (2011). Happy people live longer: Subjective wellbeing contributes to health and longevity. Applied Psychology: Health and WellBeing, 3(1), 1-43.

16. Pressman, S. D., Cohen, S. (2005). Does positive affect influence health? Psychological Bulletin, 131, 925-971.

17. Chida, Y., Steptoe, A. (2008). Positive psychological well-being and mortality: A quantitative review of prospective observational studies. Psychosomatic Medicine, 70, 741-756.

18. Chow, E., Tsao, M. N., Harth, T. (2004). Does psychosocial intervention improve survival in cancer? A meta-analysis. Palliative Medicine, 18, 25-31.

19. Howell, R. T., Kern, M. L., Lyubomirsky, S. (2007). Health benefits: Metaanalytically determining the impact of well-being on objective health outcomes. Health Psychology Review, 1, 83-136.

20. Luhmann, M., Schimmack, U., Eid, M. (2011). Stability and variability in the relationship between subjective well-being and income. Journal of Research in Personality, 45(2), 186-197.

21. Diener, E., Suh, E. M., Lucas, R. E., Smith, H. L. (1999). Subjective Wellbeing: Three decades of progress. Psychological Bulletin, 125(2), 276-302.

22. Headey, B., Wearing, A. J. (1992). Understanding happiness: A theory of subjective well-being. Melbourne, Australia: Longman Cheshire.

23. Howell, R. T., Kern, M. L., Lyubomirsky, S. (2007). Health benefits: Metaanalytically determining the impact of well-being on objective health outcomes. Health Psychology Review, 1, 83-136.

24. Luhmann, M., Hawkley, L. C., Eid, M., Cacioppo, J. T. (2012). Time frames and the distinction between affective and cognitive well-being. Journal of Research in Personality, 46, 431-441.

25. Luhmann, M., Hofman, W., Eid, M., Lucas, R. E. (2012). Subjective WellBeing and Adaptation to Life Events: A Meta-Analysis. Journal of Personality and Social Psychology, 102(3), 592-615.

26. Sarracino, F., Piekałkiewicz, M. (2021). The Role of Income and Social Capital for Europeans' Well-Being During the 2008 Economic Crisis. $J$ Happiness Stud, 22, 1583-1610 (2021). DOI: https://doi.org/10.1007/s10902-020-00285-X

27. Baranski, E. \& Gardiner, G. \& Lee, D. \& Funder, D. \& Zhuravlova, L. \& ect. (2020). Happiness around the World: A Combined Etic-Emic Approach across 
63 Countries. PLoS ONE November 2020. https://www.researchgate.net/publication/ 346036758_Happiness_around_the_World_A_Combined_Etic-Emic_Approach_ across_63_Countries\#fullTextFileContent

28. Sherman, A., Shavit, T., Barokas, G. et al. (2021). On the Role of Personal Values and Philosophy of Life in Happiness Technology. J Happiness Stud 22, 10551070.

29. Литвинчук, А. І., Можаровська, Т. В. (2020). Особливості переживання почуття щастя молоддю і дорослими в умовах заходів протидії COVID-19. Науковий часопис НПУ імені М. П. Драгоманова. Психологічні науки, 10 (55), 47-56. DOI: https://doi.org/10.31392/NPU-nc.series12.2020.10(55).05

30. Каргіна, Н. В. (2018). Ресурси та чинники психологічного благополуччя особистості. Дис. канд. псих. наук. Одеса: Державний заклад «Південноукраїнський національний педагогічний університет імені К. Д. Ушинського».

\section{References} 575.

1. Diener, E. (1984.) Subjective well-being. Psychological Bulletin, 95, 542-

2. Kahneman, D., Diener, E., Schwarz, N. (1999). Well-being: The Foundations of Hedonic Psychology. NY.: Russell Sage Found, 3-25.

3. Keyes, C. L. M., Shmotkin, D., Ryff, C. D. (2002). Optimizing well-being: The empirical encounter of two traditions. Journal of Personality and Social Psychology, 82, 1007-1022.

4. Busseri, M. A., Sadava, S. W. (2011). A review of the tripartite structure ofsubjective wellbeing: Implications for conceptualization, operationalization, analysis, and synthesis. Personality and Social Psychology Review, 15(3), 290-314.

5. Linley, P. A., Maltby, J., Woodc, A. M., Osborne, G., Hurling, R. (2009). Measuring happiness: The higher order factor structure ofsubjective and psychological wellbeing measures. Personality and Individual Differences, 47, 878884.

6. Schimmack, U. (2008). The structure of subjective well-being. The science of subjective well-being. New York, NY US: Guilford Press, 97-123.

7. Bradburn, N. M. (1965). Reports on Happiness. A Pilot Study of Behavior Related to Mental Health. Aldine Publishing Company. Chicago, USA.

8. Diener, E., Emmons, R., Larsen, R. at al. (1985). The Satisfaction with Life Scale. Journal of Personality Assessment, 49, 71-75.

9. Waterman, A. S., Schwartz, S. J., Conti R. (2008). The implications of two conceptions of happiness (hedonic enjoyment and eudaimonia) for the understanding of intrinsic motivation. Journal of Happiness Studies, 9, 41-79.

10. Bradburn, N. (1969). The Structure of Psychological well-being. Chicago: Aldine Pub. Co.

11. Ryff, C. D. (1989). Happiness is everything, or is it? Explorations on the meaning of psychological wellbeing. Journal of Personality and Social Psychology, 57, 1069-1081. 
12. Ryff, C. D. (1995). The structure of psychological well-being revisited. Journal of Personality and Social Psychology, 69, 719-727.

13. Samman, E. (2007). Psychological and Subjective Wellbeing: A Proposal for Internationally Comparable Indicators. OPHI WORKING PAPER, 05.

14. Vernik, O. (2019). Ekopsykholohichnyi pidkhid do doslidzhennia blahopoluchchia osobystosti: seredovyshchno-zhyttiediialnisnyi kontekst [Ecopsychological approach to the study of individual well-being: environmental and life context]. Aktualni problemy psykholohii - Current problems of psychology, 7(47), 68-79 [in Ukrainian].

15. Diener, E., Chan, M. Y. (2011). Happy people live longer: Subjective wellbeing contributes to health and longevity. Applied Psychology: Health and WellBeing, 3(1), 1-43.

16. Pressman, S. D., Cohen, S. (2005). Does positive affect influence health? Psychological Bulletin, 131, 925-971.

17. Chida, Y., Steptoe, A. (2008). Positive psychological well-being and mortality: A quantitative review of prospective observational studies. Psychosomatic Medicine, 70, 741-756.

18. Chow, E., Tsao, M. N., Harth, T. (2004). Does psychosocial intervention improve survival in cancer? A meta-analysis. Palliative Medicine, 18, 25-31.

19. Howell, R. T., Kern, M. L., Lyubomirsky, S. (2007). Health benefits: Metaanalytically determining the impact of well-being on objective health outcomes. Health Psychology Review, 1, 83-136.

20. Luhmann, M., Schimmack, U., Eid, M. (2011). Stability and variability in the relationship between subjective well-being and income. Journal of Research in Personality, 45(2), 186-197.

21. Diener, E., Suh, E. M., Lucas, R. E., Smith, H. L. (1999). Subjective Wellbeing: Three decades of progress. Psychological Bulletin. Vol. 125(2), 276-302.

22. Headey, B., Wearing, A. J. (1992). Understanding happiness: A theory of subjective well-being. Melbourne, Australia: Longman Cheshire.

23. Howell, R. T., Kern, M. L., Lyubomirsky, S. (2007). Health benefits: Metaanalytically determining the impact of well-being on objective health outcomes. Health Psychology Review, 1, 83-136.

24. Luhmann, M., Hawkley, L. C., Eid, M., Cacioppo, J. T. (2012). Time frames and the distinction between affective and cognitive well-being. Journal of Research in Personality, 46, 431-441.

25. Luhmann, M., Hofman, W., Eid, M., Lucas, R. E. (2012). Subjective WellBeing and Adaptation to Life Events: A Meta-Analysis. Journal of Personality and Social Psychology, 102(3), 592-615.

26. Sarracino, F., Piekałkiewicz, M. (2021). The Role of Income and Social Capital for Europeans' Well-Being During the 2008 Economic Crisis. J Happiness Stud 22, 1583-1610. DOI: https://doi.org/10.1007/s10902-020-00285-x

27. Baransk, E. \& Gardiner, G. \& Lee, D. \& Funder, D. \& Zhuravlova, L. \& ect. (2020). Happiness around the World: A Combined Etic-Emic Approach across 
63 Countries. PLoS ONE, 15(12): e0242718. DOI: https://doi.org/10.1371/journal. pone. 0242718

28. Sherman, A., Shavit, T., Barokas, G. et al. (2021). On the Role of Personal Values and Philosophy of Life in Happiness Technology. J Happiness Stud 22, 10551070 .

29. Lytvynchuk, A. I., Mozharovska, T. V. (2020). Osoblyvosti perezhyvannia pochuttia shchastia moloddiu i doroslymy $\mathrm{v}$ umovakh zakhodiv protydii COVID-19 [Features of experiencing feelings of happiness by young people and adults in the face of countermeasures COVID-19]. Naukovyi chasopys NPU imeni M. P. Drahomanova. Psykholohichni nauky - Scientific journal of NPU named after M. P. Dragomanova. Psychological sciences, 10(55), 47-56. DOI: https://doi.org/10.31392/NPU-nc.series12.2020.10(55).05 [in Ukrainian].

30. Kargina, N. V. (2018). Resursy ta chynnyky psykholohichnoho blahopoluchchia osobystosti [Resources and factors of psychological well-being of the individual]. Candidate's thesis. Odessa: State Institution "South Ukrainian National Pedagogical University named after K. D. Ushinsky» [in Ukrainian].

Received: 02.05.2021

Accepted: 16.05.2021 